\title{
Commercially Important Marine Mollusks for Human Consumption in Acapulco, México
}

\author{
Rafael Flores-Garza ${ }^{1}$, Sergio García-Ibáñez ${ }^{1}$, Pedro Flores-Rodríguez ${ }^{1}$, \\ Carmina Torreblanca-Ramírez ${ }^{1}$, Lizeth Galeana-Rebolledo ${ }^{1}$, Arcadio Valdés-González ${ }^{2}$, \\ Arquímedes Suástegui-Zárate ${ }^{1}$, Juan Violante-González ${ }^{1}$ \\ ${ }^{1}$ Unidad Académica de Ecología Marina, Universidad Autónoma de Guerrero, Acapulco, México; ${ }^{2}$ Facultad de Ciencias Biológicas, \\ Universidad Autónoma de Nuevo León, Ciudad Universitaria, San Nicolás de los Garza, México. \\ Email: rfloresgarza@yahoo.com
}

Received December $17^{\text {th }}$, 2011; revised January $20^{\text {th }}$, 2012; accepted January $30^{\text {th }}, 2012$

\begin{abstract}
Acapulco, offers for international tourism a variety of mollusks that are delightful to the palate and a source of economic revenue for its residents; however there are no studies on the species consumed. Furthermore, data from the State agencies responsible for registration of these products are unclear. This work is aimed to develop an inventory of Gastropoda, Bivalvia and Polyplacophora marketed as food, to gain knowledge on the species native to Acapulco and the introduced ones. The places that sell shellfish were interviewed from 2008 to 2011 in order to determine the geographical origin of their products being offered. We identified 42 species: 15 species of gastropods are captured locally and three are introduced. On Bivalvia, seven species are caught locally and 16 are introduced. There are Bivalvia species caught locally; however, their capture is now unaffordable. It is likely that this situation is due to overfishing and/or the transmission of diseases or parasites caused by the introduction of foreign living organisms to Acapulco. Within the list of species caught locally, there are some listed as of subject protection; all of these organisms are exploited in Acapulco without control. The wealth of marine mollusks for human consumption in Acapulco is very high. The capture does not satisfy local market demand and the amount of introduced species is very high. It is necessary to make a diagnostic analysis of mollusk fishing industry in the state of Guerrero, also implement a management program, including the sanitary measures and control of introduced species, as they arrive alive and stay alive in the waters of Acapulco. A significant number of native species that have aquaculture potential should be studied for commercial culture practice as well as to conduct studies on their biology on those species that are considered over-exploited and allow recovery of the species in its habitat.
\end{abstract}

Keywords: Mollusks; Commercial; Consumption; Human; Acapulco; México

\section{Introduction}

The marine mollusks are very important since many of them are used as food, they also have other uses such as crafts making, to dye cotton, yarn and clothes, etc., so it is that they have received special attention and become a natural resource of economic importance.

Like any natural resource, this must be used and managed properly; otherwise it runs the risk of over exploitation and running out. For proper administration and management of a natural resource such as mollusks, there must be studies to assess biodiversity, species by location, the dynamics of populations and communities, including aspects on reproductive cycles with which to determine seasonal minimum sizes and catch volumes. These studies are the technical and scientific basis with which it must developed management plans to allow proper and sustain- able use of these resources, and these studies should also encourage the recovery of the species and its habitat.

Acapulco's wide stretch of coastline offers beautiful beaches for tourism, and provides a variety of edible marine mollusks that are a delight to the palate and a major source of revenue for fishermen and tourist servers. Hence, marine mollusks have an important role in the economic and cultural life of the municipality of Acapulco.

For Mexico there is important literature on comercially important shellfish [1-3].

The work on mollusks for Guerrero, consists on basic studies of diversity, community structure, geographic distribution, distribution areas and associated fauna [4-12]. There is little literature on commercial species populations for the State of Guerrero [13-18] and is based on some of the species considered as the most important, as are clams Megapitaria aurantiaca (Sowerby, 1831), M. 
squalid (Sowerby, 1835) and Dosinia ponderosa (Gray, 1838), the purple snail Plicopurpura pansa (Gould, 1853) and the sea cockroach Chiton articulatus (Sowerby, 1832).

In the case of Acapulco was not found in the literature any report on the shellfish species commonly marketed for human consumption.

On the other hand, there are government agencies responsible for monitoring and recording the products obtained from the fisheries, to regulate and monitors the introduction of fishery products coming from other states of the country and are introduced on to the State of Guerrero. The records of government agencies relating to fishing and the introduction of mollusks are quite confusing and inaccurate.

Based on the afore mentioned, this study was aimed to elaborate a diagnostic analysis that includes inventorying the species (Gastropoda, Bivalvia and Polyplacophora) marketed for human consumption in Acapulco, Guerrero, in addition learn on the species which are captured in nearby and the introduced ones; as well as serving of support to advance the construction of appropriate management plans in the shellfish fishery. On the other hand, not having control of introduced species up to now, allows the flow of diseases and parasites arriving with them. It is also aimed to provide information needed for the realization of the marine mollusk fisheries management plan in the state of Guerrero.

\section{Methods and Materials}

Acapulco municipality is located between $16^{\circ} 52^{\prime}$ and $16^{\circ} 41^{\prime} \mathrm{N}$ and $99^{\circ} 29^{\prime}$ and $100^{\circ} 11^{\prime} \mathrm{W}$. The littoral reaches 62 $\mathrm{km}$ in length. Acapulco's Bahía de Santa Lucia is the most important bay in the municipality, at the same time it is the longest (13 km length), and its maximum width is six $\mathrm{km}[19]$.

In the present work, visits were made at different places where mollusks are sold in the municipality of Acapulco for sampling organisms and interviewing people in charge of captures and/or mollusks trading. Site selection was based on the quantity and variety of mollusks that are sold and the frequency with which the site was found giving service to the public. Also were interviewed the fisherman that capture and sell mollusks directly to the consumer, whom traded their sale mainly at the beaches where they land with their capture, besides sampling directly the specimens they sold.

Samplings were made from 2008 to 2011 in 19 places where mollusks trading occurs, located at Centro, Hornos, Playa la Angosta, Caleta, Caletilla, Pie de la Cuesta, and Puerto Marqués (Table 1). In each site specimens were collected that according to the interviewed fishermen and traders were the most demanded for human consumption. All of the sampled material were labeled and placed individually in plastic bags.
Table 1. Sites where samples of marine mollusks of commercial importance for human consumption were harvested in Acapulco, Guerrero, Mexico.

\begin{tabular}{|c|c|c|}
\hline Zone & Station & Coordinates \\
\hline \multirow{2}{*}{ Centro } & La Noria & $\begin{array}{c}\text { N16 } 56^{\circ} 14.3^{\prime \prime} \\
\text { W099 } 544^{\circ} 11.3^{\prime \prime}\end{array}$ \\
\hline & Buzos II & $\begin{array}{l}\text { N16 } 56^{\circ} 14.3^{\prime \prime} \\
\text { W099 } 54 \text { '11.3" }\end{array}$ \\
\hline Hornos & El Muelle & $\begin{array}{c}\mathrm{N} 16^{\circ} 51^{\prime} 06.2^{\prime \prime} \\
\text { W099 } 54^{\circ} 02.0^{\prime \prime}\end{array}$ \\
\hline \multirow{2}{*}{ La Angosta } & Perla del Mar & $\begin{array}{c}\text { N16 }{ }^{\circ} 50 ' 31.8^{\prime \prime} \\
\text { W099 } 54^{\circ} 50.7^{\prime \prime}\end{array}$ \\
\hline & Candy Mar & $\begin{array}{c}\text { N16 } 50 ' 30.9^{\prime \prime} \\
\text { W099 } 54^{\circ} 50.1^{\prime \prime}\end{array}$ \\
\hline \multirow{11}{*}{ Caleta } & El Navegante & $\begin{array}{l}\text { N16 }{ }^{\circ} 49^{\prime} 53.3^{\prime \prime} \\
\text { W99 } 54^{\prime} 18.8^{\prime \prime}\end{array}$ \\
\hline & La Esperanza & $\begin{array}{l}\text { N16²49'53.3" } \\
\text { W99 } 54^{\circ} 18.8^{\prime \prime \prime}\end{array}$ \\
\hline & Dragón de Oro & $\begin{array}{l}\text { N16 } 46^{\circ} ' 53.3^{\prime \prime} \\
\text { W99 } 54^{\prime} 18.8^{\prime \prime}\end{array}$ \\
\hline & Maria Bonita & $\begin{array}{l}\text { N16 } 46^{\circ} 49^{\prime} 53.3^{\prime \prime} \\
\text { W99 } 54^{\prime} 18.8^{\prime \prime}\end{array}$ \\
\hline & Capullo & $\begin{array}{l}\text { N16 } 46^{\circ} 49^{\prime} 53.3^{\prime \prime} \\
\text { W99 } 54^{\prime} 18.8^{\prime \prime}\end{array}$ \\
\hline & El Mariachi & $\begin{array}{l}\text { N16 }{ }^{\circ} 49^{\prime} 53.3^{\prime \prime} \\
\text { W99 } 54 ' 18.8^{\prime \prime}\end{array}$ \\
\hline & Bambú & $\begin{array}{l}\text { N16 }{ }^{\circ} 49^{\prime} 53.3^{\prime \prime} \\
\text { W99 } 54 ' 18.8^{\prime \prime}\end{array}$ \\
\hline & Mar Paraíso & $\begin{array}{l}\text { N16 } 46^{\circ} 49^{\prime} 53.3^{\prime \prime} \\
\text { W99 } 54^{\prime} 18.8^{\prime \prime}\end{array}$ \\
\hline & Bocamar & $\begin{array}{l}\text { N16 } 46^{\circ} 53.3^{\prime \prime} \\
\text { W99 } 54^{\circ} 18.8^{\prime \prime}\end{array}$ \\
\hline & Poseidón & $\begin{array}{l}\text { N16 } 46^{\circ} 49^{\prime} 53.3^{\prime \prime} \\
\text { W99 } 54^{\prime} 18.8^{\prime \prime}\end{array}$ \\
\hline & La Roqueta & $\begin{array}{l}\text { N16 } 46^{\circ} 49^{\prime} 53.3^{\prime \prime} \\
\text { W99 } 54^{\prime} 18.8^{\prime \prime}\end{array}$ \\
\hline \multirow{2}{*}{ Caletilla } & Rompe Olas & $\begin{array}{c}\text { N16 } 49^{\circ} 53.3^{\prime \prime} \\
\text { W099 } 544^{\prime} 10.0^{\prime \prime}\end{array}$ \\
\hline & La Cabaña & $\begin{array}{l}\text { N16 } 49^{\circ} 55.2^{\prime \prime} \\
\text { W099 } 54^{\circ} 12.0^{\prime \prime}\end{array}$ \\
\hline Pie de la Cuesta & El Derrumbe & $\begin{array}{c}\text { N1652'09.3" } \\
\text { W099 } 56^{\prime} 06.2^{\prime \prime}\end{array}$ \\
\hline
\end{tabular}

The times of visits to a sampling site were as many as considered needed for gathering a representative sample of organisms. A sample was considered representative when, by visiting the site, no new information was gained than what was recorded in previous occasions.

To establish the geographical origin of the species, an interview was applied to current people at sampling intake, which consisted in four open questions; the first one was for knowing if the harvested species was captured in Acapulco or if it had its origin in another place and then introduced to the municipality. The second question was realized only if the harvested species was introduced, and consisted in knowing its place of origin. The third one had the objective of knowing if the introduced species that was currently being harvested, had being captured previously in Acapulco. The fourth question was followed only if the answer to question three was that the harvested spe- 
cies was indeed captured previously in Acapulco, and it had the objective of knowing, under the interviewed person's opinion, the possible causes why that species is not captured anymore in Acapulco. The interview and all the collected information were recorded in a field book.

When finished harvesting, preservation of specimens was made by placing the labeled bagged specimens in bottles with $96 \%$ ethyl alcohol and subsequently, transported to the laboratory for their identification. Accurate taxonomical id required a confirmation phase in laboratory through qualified staff and the use of specialized literature [20-24], taxonomical actualizations were made $[25,26]$. After specimens were identified, they were placed in the malacology collection of "Unidad Académica de Ecología Marina de la Universidad Autónoma de Guerrero".

\section{Results}

Forty-two species of marine mollusks that are comercialized in Acapulco for human consumption were found, from which, 18 were Gastropoda, 23 Bivalvia, and one was Polyplacophora.

From the overall total, 23 are captured in Acapulco, 17 are species introduced to the municipality to be sold as food, and two species are local captured and at the same time are being introduced from other places of the Republic into the municipality for its commercialization.

For Gastropoda, 15 species are captured in Acapulco for its commercialization and three species are introduced. The best represented family was Muricidae, presenting seven species from which, all seven are captured locally (Table 2).

While on Bivalvia, seven species was captured in Acapulco and 14 introduced from other regions of the country for human consumption. Two species, Hyotissa hyotis (Linnaeus, 1758) and Crassostrea prismatica (Gray, 1825), were captured in Acapulco and are as well introduced to the municipality for its trading.

The best represented families were Veneridae and Arcidae, each with five species. Meanwhile on Veneridae, all species are introduced and come from states located on the north of the Republic; and for Arcidae, three species are introduced and two captured locally (Table 3).

From Polyplacophora only one species was found harvested, Chiton articulatus (Sowerby, 1832), which is captured locally (Figure 1).

Places from where mollusks are being introduced most frequently into Acapulco for human consumption were Costa Chica from the State of Guerrero, and from the states of Baja California Sur, Sinaloa, Sonora, Oaxaca, Nayarit, and Veracruz.

The clams Chione undatella (Sowerby, 1835), Periglypta multicocostata (Sowerby, 1835), Megapitaria squalida (Sowerby, 1835), and M. aurantiaca (Sowerby, 1831) were captured and commercialized in Acapulco, however, lately the populations have decreased to a level where there are not enough specimens to make it profitable and its exploitation is unaffordable.

Pinctada mazatlanica (Hanley, 1856), Spondylus calcifer Carpenter, 1757, and Plicopurpura pansa (Gould, 1853) are recorded at the statute of "Norma Oficial Mexicana NOM-059-SEMARNAT-2010" [27] and are under special protection, in spite of that, these species are exploited in Acapulco for human consumption without any control (Figure 2).

Table 2. Origin of families and species of gastropods (local and introduced) found in Acapulco, Guerrero, Mexico, that were commercialized for human consumption.

\begin{tabular}{|c|c|c|}
\hline Species & Origin & Provenance \\
\hline \multicolumn{3}{|l|}{ Muricidae } \\
\hline Muricanthus radix (Gmelin, 1971) & Local & Acapulco \\
\hline Muricanthus princeps (Broderip, 1833) & Local & Acapulco \\
\hline $\begin{array}{l}\text { Chicoreus (P.) erythrostomus } \\
\text { (Swainson, 1831) }\end{array}$ & Local & Acapulco \\
\hline Chicoreus (P.) regius (Swainson, 1831) & Local & Acapulco \\
\hline Neoropana muricata (Broderip, 1832) & Local & Acapulco \\
\hline Mancinella speciosa (Valenciennes, 1832) & Local & Acapulco \\
\hline Plicopurpura pansa (Gould, 1853) & Local & Acapulco \\
\hline \multicolumn{3}{|l|}{ Fasciolariidae } \\
\hline Opeatostoma pseudodon (Burrow, 1815) & Local & Acapulco \\
\hline Fasciolaria (P.) princeps Sowerby, 1825 & Introduced & $\begin{array}{l}\text { Costa Chica, } \\
\text { Guerrero and } \\
\text { Oaxaca }\end{array}$ \\
\hline Leucozonia cerata (Wood, 1828) & Local & Acapulco \\
\hline \multicolumn{3}{|l|}{ Strombidae } \\
\hline Strombus (T.) galeatus Swainson, 1823 & Introduced & $\begin{array}{l}\text { Costa Chica, } \\
\text { Guerrero and } \\
\text { Oaxaca }\end{array}$ \\
\hline Strombus peruvianus Swainson, 1823 & Introduced & $\begin{array}{l}\text { Costa Chica, } \\
\text { Guerrero and } \\
\text { Oaxaca }\end{array}$ \\
\hline Strombus (S.) gracilior Sowerby, 1825 & Local & Acapulco \\
\hline \multicolumn{3}{|l|}{ Vasidae } \\
\hline Vasum caestus (Broderip, 1833) & Local & Acapulco \\
\hline \multicolumn{3}{|l|}{ Calyptraeidae } \\
\hline Crucibulum scutellatum (Wood, 1828) & Local & Acapulco \\
\hline Crucibulum umbrella (Deshayes, 1830) & Local & Acapulco \\
\hline \multicolumn{3}{|l|}{ Melongenidae } \\
\hline Melongena corona (Gmelin, 1791) & Local & Acapulco \\
\hline \multicolumn{3}{|l|}{ Fissurellidae } \\
\hline Fissurella (C.) gemmata Menke, 1847 & Local & Acapulco \\
\hline
\end{tabular}


Table 3. Origin of families and species of Bivalvia and Polyplacophora (local and introduced) found in Acapulco, Guerrero, Mexico, that were commercialized for human consumption.

\begin{tabular}{|c|c|c|}
\hline Species & Origin & Provenance \\
\hline \multicolumn{3}{|c|}{$\begin{array}{c}\text { Bivalvia } \\
\text { Veneridae }\end{array}$} \\
\hline $\begin{array}{l}\text { Megapitaria aurantiaca } \\
\text { (Sowerby, 1831) }\end{array}$ & Introduced & $\begin{array}{l}\text { La Paz BCS, } \\
\text { Sinaloa, Sonora }\end{array}$ \\
\hline $\begin{array}{l}\text { Megapitaria squalida } \\
\text { (Sowerby, 1831) }\end{array}$ & Introduced & $\begin{array}{l}\text { La Paz BCS, } \\
\text { Sinaloa }\end{array}$ \\
\hline $\begin{array}{l}\text { Chione undatella } \\
\text { (Sowerby, 1835) }\end{array}$ & Introduced & $\begin{array}{l}\text { Baja California } \\
\text { Sur, Sinaloa }\end{array}$ \\
\hline $\begin{array}{l}\text { Periglypta multicostata } \\
\quad \text { (Sowerby, 1835) }\end{array}$ & Introduced & $\begin{array}{l}\text { La Paz BCS, } \\
\text { Sinaloa }\end{array}$ \\
\hline $\begin{array}{l}\text { Chione californiensis } \\
\text { (Broderip, 1835) }\end{array}$ & Introduced & Baja California Sur \\
\hline \multicolumn{3}{|c|}{ Arcidae } \\
\hline $\begin{array}{l}\text { Anadara }(R .) \text { formosa } \\
\quad \text { (Sowerby, 1833) }\end{array}$ & Local & Acapulco \\
\hline $\begin{array}{c}\text { Anadara (L.) grandis } \\
\text { (Broderip \& Sowerby, 1829) }\end{array}$ & Introduced & $\begin{array}{l}\text { Sinaloa, Nayarit \& } \\
\text { Baja California Sur }\end{array}$ \\
\hline $\begin{array}{l}\text { Anadara (L.) multicostata } \\
\text { (Sowerby, 1833) }\end{array}$ & Introduced & Baja California Sur \\
\hline $\begin{array}{c}\text { Anadara (A.) tuberculosa } \\
\text { (Sowerby, 1833) }\end{array}$ & Introduced & Baja California Sur \\
\hline Barbatia reeveana (Linnaeus, 1758) & Local & Acapulco \\
\hline \multicolumn{3}{|c|}{ Pectinidae } \\
\hline $\begin{array}{l}\text { Argopecten circularis } \\
\text { (Sowerby, 1835) }\end{array}$ & Introduced & Baja California Sur \\
\hline $\begin{array}{l}\text { Nodipecten subnodosus } \\
\text { (Sowerby, 1835) }\end{array}$ & Introduced & Baja California Sur \\
\hline \multicolumn{3}{|c|}{ Pinnidae } \\
\hline Pinna rugosa Sowerby, 1835 & Local & Acapulco \\
\hline \multicolumn{3}{|c|}{ Pteriidae } \\
\hline Pinctada mazatlanica (Hanley, 1856) & Local & Acapulco \\
\hline \multicolumn{3}{|c|}{ Chamidae } \\
\hline Chama (C.) coralloides (Olson, 1971) & Local & Acapulco \\
\hline \multicolumn{3}{|l|}{$\begin{array}{l}\text { Chama (C.) mexicana } \\
\text { Carpenter, } 1857\end{array}$} \\
\hline \multicolumn{3}{|c|}{ Ostreidae } \\
\hline Crassostrea gigas Thunberg 1793 & Introduced & Sonora and Veracruz \\
\hline Crassostrea prismatica (Gray, 1825) & $\begin{array}{l}\text { Local and } \\
\text { Introduced }\end{array}$ & $\begin{array}{l}\text { Costa Chica de } \\
\text { Guerrero \& } \\
\text { Acapulco }\end{array}$ \\
\hline $\begin{array}{l}\text { Crassostrea virginica } \\
\text { (Gmelin, 1791) }\end{array}$ & Introduced & Veracruz \\
\hline \multicolumn{3}{|c|}{ Mytilidae } \\
\hline Modiolus capax (Conrad, 1837) & Introduced & Veracruz \\
\hline \multicolumn{3}{|c|}{ Gryphaeidae } \\
\hline Spondylus calcifer Carpenter, 1757 & Local & Acapulco \\
\hline Hyotissa hyotis (Linnaeus, 1758) & $\begin{array}{l}\text { Local and } \\
\text { Introduced }\end{array}$ & Acapulco \\
\hline \multicolumn{3}{|c|}{ Psammobidae } \\
\hline Gary (G.) maxima (Deshayes, 1855) & Local & Acapulco \\
\hline \multicolumn{3}{|c|}{ Polyplacophora } \\
\hline \multicolumn{3}{|c|}{ Chitonidae } \\
\hline Chiton articulatus (Sowerby, 1832) & Local & Acapulco \\
\hline
\end{tabular}

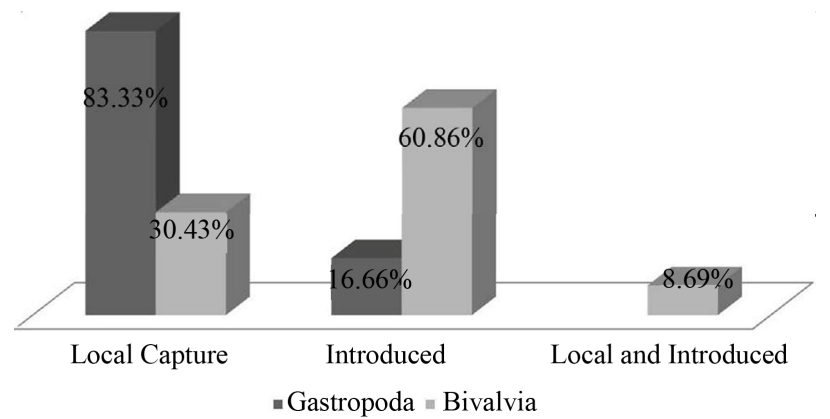

Figure 1. Percentage of species Gastropeda and Bivalvia that are captured locally and the introduced ones for human consumption in Acapulco, Guerrero.

\section{Discussion and Conclusion}

Species richness of marine mollusks for human consumption found in Acapulco is very high, in order to the grand existing demand of these species, above all being Acapulco a national and internationally touristic harbor of such importance where part of the attraction services are its beautiful beaches and the rich variety on its cuisine of dishes made basically out of mollusks and seafood items.

The amount of introduced species for its commercialization for human consumption is very high and represents $40.47 \%$ from total of species found in this present research.

Introduced species is something that would be expected to be found in a study of this matter, given that mollusks demand by tourists and by its local inhabitants is very high, and local capture could not satisfy market demand.

To satisfy this demand in Acapulco, the mollusks fishery in the municipality is artisanal and mainly for auto-consumption, local trading in restaurants, for direct sale from fisherman to consumers and in some cases to the market; it is based on the exploitation of natural banks; it is a riparian and a rustic activity. All the aforementioned reduces significantly the possibility for increment on the production.

On the other hand, there are no aquaculture units that produce mollusks in the municipality, whereby attempts for satisfaction of the local market demand, drives to the introduction of species collected abroad.

Most of species that are fished in Acapulco for human consumption belong to class Gastropoda, and most of the species introduced to Acapulco for its commercialization are from class Bivalvia. Within Gastropoda, family Muricidae is the best represented and all species are captured locally. In class Bivalvia two families were the best represented, both with five species each. From the 10 species that represent both families, only two are fished in Acapulco for human consumption, Anadara formosa (Sowerby, 1833) and Barbatia reeveana (Linnaeus, 1758). There are species of Bivalvia that were used to be 


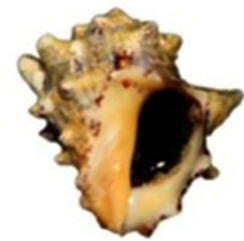

(a)

(f)

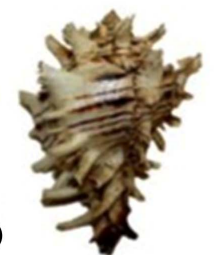

(k)

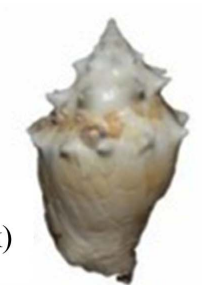

(b)
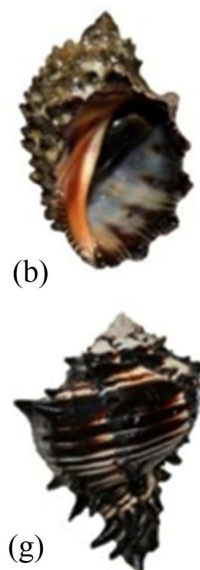

(c)
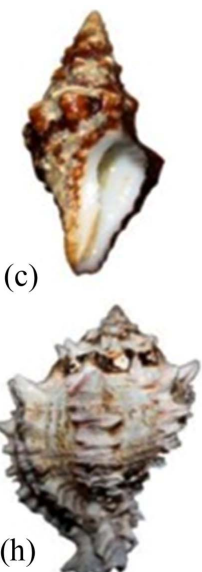

(h)

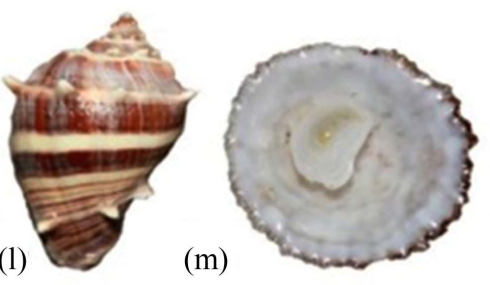

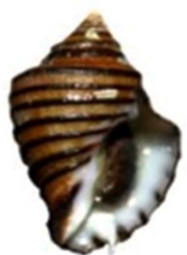

(d)

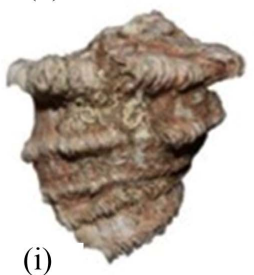

(j)

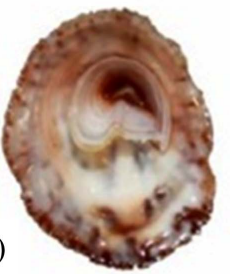

(e)
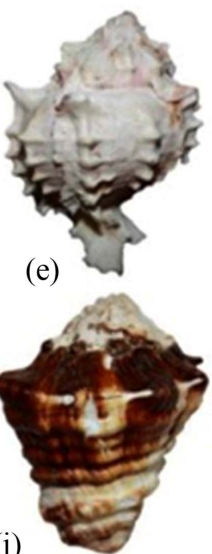

(o)

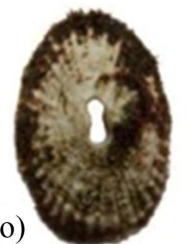

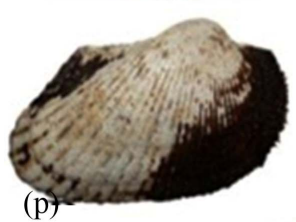

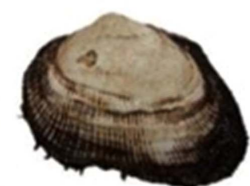

(q)

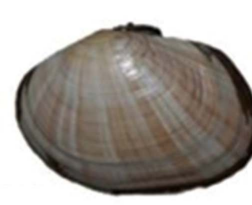

(r)

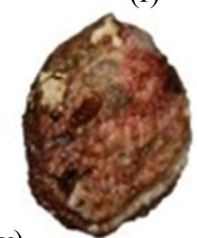

(v)

(w)

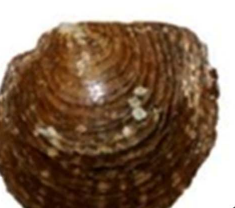

(s)

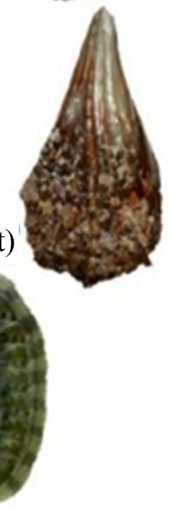

Pictures collection of marine invertebrates. Unided Académica de Ecologia Marina. Universidad Autónoma de Guerrero (a) Maninella speciosa; (b) Plicopurpura pansa; (c) Leucozonia cerata; (d) Opeatostoma pseudodon; (e) Chicoreus erythrostomus; (f) Muricanthus princeps; (g) Muricanthus radix; (h) Chicoreus regius; (i) Neoropanna muricata; (j) Vasum caestus; (k) Strombus gracilior; (l) Melongena corona; (m) Crucibulum scutellatum; (n) Crucibulum umbrella; (o) Fissurella gemmata; (p) Anadara formosa; (q) Barbatia reeveana; (r) Gary maxima; (s) Pinctada mazatlanica; (t) Chama coralloides; (u) Chama mexicana; (v) Crassostrea primatica; (w) Pinna rugosa; (x) Chiton articulatus.

Figure 2. Local species of Gastropoda, Bivalvia and Polyplacophora found in Acapulco, Guerrero, Mexico, that were commercialized for human consumption.

captured locally for its market; nonetheless nowadays its capture is unaffordable given its population scarcity. It is worth to mentioned that in both fisherman's and mollusks merchant's interviews, all agreed that clams Megapitaria aurantica, M. squalida, Periglypta multicostata, and Chione undatella were previously fished in riparian waters of Acapulco's municipality, but currently their population has been reduced to such grade that it is not possible to capture them for commercial matters.

A hypothesis about population diminishment is overexploitation of these species, but this is not possible to confirm because of the inconsistencies on the data that governmental departments are responsible of recording from the mollusks fisheries on the State of Guerrero.

Moreover it is known that, at least for 20 years given that high tourism seasons arriving to the harbor in great quantities for holidays, and thus local capture could not satisfy market demand, clams have been introduced coming from several states located north of the Republic. This clam introduction has been since that day until today and it has been occurring without neither regard nor health control. The issue of clam introduction sharpens above all because they arrive alive into Acapulco and to keep them alive they are placed on the seabed of shallow places in cages or sacs, these places are near the place where mollusks are commercialized. Hence, the possi- 
bility is that there could have been a transmission of parasites or diseases that had caused or enhanced mortality over native population beside the overexploitation theory.

On the other hand, the information records about mollusks sale in governmental agencies is confusing or lacking, thus it is in great needed to make a fishery diagnosis of marine mollusks in the State of Guerrero, besides establishing control over introduced species and develop adequate management program and strategies for marine mollusks fisheries of commercial importance populations, this management should include record of the species that are introduced and their amounts, origin, and health control given that they arrive alive and are kept alive in Acapulco's marine waters.

We are in accordance with Ríos-Jara et al. (2008) that an important quantity of species such as the clam Anadara (L.) grandis (Broderip and Sowerby, 1829), the oyster Crassostrea prismatica (Gray, 1825), the Spondilus calcifer and the gastropods of the genera Muricanthus and Chicoreus, that are native species have an important aquaculture potential and are considered species with commercial culturing potential.

These species and others that are native should be studied for their commercial culture potential, thus it is important to recommend the start of pilot crops where tested technology is applied to similar or same species.

It is important to remark the necessity for implementing several programs by the municipality of Acapulco in relation to mollusks of commercial importance for human consumption, among them the studies of fisheries biology for those species that are considered to be overly exploited, and on the issue of efficient on obtaining and ordering data to consolidate fisheries management schemes, beside those skemes and strategies that will allow the species recovery in their habitats and to conduct self sustainable fisheries.

Some species in the statute and bylaws of the "Norma Oficial Mexicana NOM-059-SEMARNAT-2010 (Protección ambiental-Especies nativas de México de flora y fauna silvestres-Categorías de riesgo y especificaciones para su inclusión, exclusión o cambio-Lista de especies en riesgo)" are recorded as protected species, and are commercialized in Acapulco for human consumption with no control or guarding, for what was observed in the harbor during the time of this project was conducted.

\section{Acknowledgements}

We thank the Universidad Autónoma de Guerrero for the support and partial funding of this study and the research projects. The current state of the marine mollusc fishery, economic analysis of catches and socio-economic development of the SCPP on the coast of the Municipality of Acapulco, Guerrero.

\section{REFERENCES}

[1] E. Baqueiro, J. A. Masso and H. B. Guajardo, "Distribución y Abundancia de Moluscos de Importancia Comercial en Baja California Sur, México,” Instituto Nacional de la Pesca, México, Serie de Divulgación, 1982.

[2] E. Baqueiro and D. Aldana, "Patrones en la Biología Poblacional de Moluscos de Importancia Comercial en México,” Revista Biológica Tropical, Vol. 51, No. 4, 2003, pp. 97-107.

[3] E. Rios-Jara, C. M. Navarro-Cervantes, S. SarmientoNafate, C. M. Galván-Villa and E. Lopez-Uriarte, "Bivalvos y Gasterópodos (Mollusca) de Importancia Comercial y Potencial de las Costas de Chiapas y Oaxaca, México," Ciencia y Mar, Vol. 12, No. 35, 2008, pp. 3-20.

[4] E. Villalpando, "Diversidad y Zonación de Moluscos de Facie Rocosa Isla Roqueta, Acapulco Guerrero,” BA Thesis, Universidad Nacional Autónoma de México, México D.F., 1986.

[5] V. Delgado-Blas, "Estudio Sistemático y Aspectos Ecológicos de Gasterópodos de la Facie Rocosa de la Bahía de Acapulco, Guerrero, México,” BA Thesis, Universidad Autónoma de Guerrero, Acapulco, 1989.

[6] J. García, "Fauna Malacológica de Acompañamiento del Caracol Purpura pansa Gould1853 en la Zona Mesolitoral de la Isla Roqueta, Acapulco, Guerrero, México,” Degree Thesis, Universidad Autónoma de Guerrero, Acapulco, 1994.

[7] P. Flores, R. Flores, S. García and A. Valdés, "Riqueza and Diversidad de la Malacofauna del Mesolitoral Rocoso de la Isla la Roqueta, Acapulco, Guerrero, México,” Ciencia, Revista de Investigación Científica, Vol. 2, No. 11, 2003, pp. 5-14.

[8] A. Valdés-González, P. Flores-Rodriguez, R. Flores-Garza and S. Garcia-Ibañez, "Molluscan Communities of the Rocky Intertidal Zone at Two Sites with Different Wave Action on Isla la Roqueta, Acapulco, Guerrero, México," Journal of Shellfish Research, Vol. 23, No 3, 2004, pp. 875-880.

[9] P. Flores, "Estructura de la Comunidad de Moluscos del Mesolitoral Superior en las Playas de Facie Rocosa del Estado de Guerrero, México,” PhD Dissertation, Universidad Autónoma de Nuevo León, San Nicolás de los Garza Nuevo León, 2004.

[10] P. Flores-Rodriguez, R. Flores-Garza, S. Garcia-Ibañez and A. Valdez Gonzales, "Variación en la Diversidad Malacológica del Mesolitoral Rocoso en Playa Troncones la Unión, Guerrero, México,” Revista Mexicana de Biodiversidad, Vol. 78, No. 2, 2007, pp. 33S-40S.

[11] F. Barba-Marino, P. Flores-Rodriguez, R. Flores-Garza, S. Garcia-Ibañez and D. G. Arana-Salvador, "Biodiversidad y Zonificación de la Comunidad de Moluscos, Que Habita el Sustrato Rocoso en dos Sitios con Distinta Acción del Oleaje, en la Isla La Roqueta, Acapulco, Guerrero, México,” In: L. J. R. Ruiz, J. G. Aguilar, S. L. A. Weiss and W. M. C. Sánchez, Eds., Perspectiva en Malacología Mexicana, Universidad Juárez Autónoma de Tabasco, Villahermosa, 2010, pp. 21-43.

[12] R. Flores-Garza, C. Torreblanca-Ramírez, P. Flores-Rodrí- 
guez, S. Garcia-Ibañez and L. Galeana-Rebolledo, "Riqueza y Análisis de la Comunidad Malacológica en el Mesolitoral Rocoso de la Playa Tlacopanocha, Acapulco, Guerrero,” In: L. J. R. Ruiz, J. G. Aguilar, S. L. A. Weiss and W. M. C. Sánchez, Eds., Perspectiva en Malacología Mexicana, Universidad Juárez Autónoma de Tabasco, Villahermosa, 2010, pp. 125-138.

[13] E. Baqueiro and J. Stuardo, “Observaciones Sobre la Biología, Ecología y Explotación de Megapitaria aurantiaca, (Sowerby, 1831), M. squalida (Sowerby, 1835) y Dosinia ponderosa (Gray, 1838) (Bivalvia: Veneridae) de la Bahía de Zihuatanejo e Isla Ixtapa, Gro. México,” Anales Del Centro de Ciencias del Mar y Limnología, No. 4, 1977, pp. 161-208.

[14] A. A. Rojas, "Análisis Biológico-Pesquero de la Cucaracha de Mar (Chiton articulatus, Sowerby 1832) de Acapulco, Gro., México,” Memories IX Congreso Nacional de Zoología, México, Universidad Juárez Autónoma de Tabasco y Sociedad Mexicana de Malacología, A. C. Villahermosa Tabasco, México, 1988, pp. 151-156.

[15] S. García-Ibáñez, R. Flores-Garza, P. Flores-Rodríguez and A. Valdes-Gonzaléz, "Densidad y Tallas de Plicopurpura patula pansa Relacionadas con el Sustrato y Oleaje en la Costa Rocosa de Guerrero, México,” Hidrobiológica, Vol. 14, No. 2, 2004, pp. 127-136.

[16] S. Garcia-Ibañez, R. Flores-Garza, P. Flores Rodríguez and D. G. Arana-Salvador, "La Cucaracha de Mar Chiton articulatus Sowerby, 1832," Revista Sinergia, Consejo de Ciencia Tecnología e Innovación del Estado de Guerrero, México, No. 2, 2009, pp. 10-13.

[17] R. Flores-Garza, P. Flores-Rodriguez, S. Garcia-Ibañez and A. Valdes-Gonzalez, "Demografía del Caracol Plicopurpura pansa (Neotaeniogloss: Muricidae) y Constitución de la Comunidad Malacol Ógica Asociada en Guerreo, México,” Revista Biológica Tropical, Vol. 55, No. 3-4, 2007, pp. 867-878.

[18] L. Galeana-Rebolledo, M. A. Suastegui-Herrera, G. Torales Gutierrez, C. A. Millan Roman, S. Garcia-Ibañez, R. Flores-Garza, P. Flores-Rodriguez and D. G Arana- Salvador, "Estudio de la Población del Chiton Articulatus Sowerby, 1832 en Playa Ventura, Copala, Guerrero, Como un Recurso de Importancia Comercial,” In: E. Ríos-Jara,
M. C. Esqueda-González and C. M. Galván-Villas, Eds., Estudios Sobre la Malacología y Conquiliología en México, Universidad de Guadalajara, Guadalajara, 2007, pp. 193195.

[19] Gobierno del Estado de Guerrero, "Enciclopedia de los Municipios de México,” Estado de Guerrero, Acapulco de Juárez, 2005.

http://www.e-local.gob.mx/work/templates/enciclo/guerre ro/municipios/12001a.htm

[20] A. M. Keen, "Sea Shells of Tropical West America," Stanford University Press, Palo Alto, 1971.

[21] P. Kaas and R. A. Van Belle, "Monograph of Living Chitons (Mollusca: Polyplacophora). Vol. 2. Suborder Ischnochitonina. Ischnochitonidae: Schizoplacinae, Callochitoninae \& Lepidochitoninae,” E. J. Brill, Leiden, 1985.

[22] P. Kaas and R. A. Van Belle, "Monograph of Living Chitons (Mollusca: Polyplacophora). Vol. 5. Suborder Ischnochitonina. Ischnochitonidae: Ischnochitoninae (Concluded), Callitoplacina; Mopaliidae. Additions to Vols. 1-4,” E. J. Brill, Leiden, 1994.

[23] A. Reyes-Gomez, "Sistemática de los Chitones (Mollusca: Polyplacophora). De la Colección de Moluscos del Instituto de Biología UNAM,” BA Thesis, Universidad Nacional Autónoma de México, México D.F., 1999.

[24] A. Reyes-Gomez and M. A. Salcedo-Vargas, "The Recent Mexican Chiton (Mollusca: Polyplacophora) Species,” The Festivus, Vol. 34, No. 2, 2002, pp. 17-27.

[25] C. Skoglund, "Panamic Province Molluscan Literature Additions and Changes from 1971 through 2000," The Festivus, I. Bivalvia, II. Polyplacophora,” The Festivus, Vol. 32, Supplement, 2001, 139 p.

[26] C. Skoglund, "Panamic Province Molluscan Literature Additions and Changes from 1971 through 2001, III Gastropoda,” The Festivus, Vol. 33, Supplement, 2001, 286 p.

[27] Anonymous, "Norma Oficial Mexicana NOM-059-ECOL2010, Protección Ambiental-Especies Nativas de México de Flora y Fauna Silvestre-Categorías de Riesgo y Especificaciones para Inclusión, Exclusión o CambioLista de Especies en Riesgo,” Diario Oficial de la Federación, 30 de Diciembre de 2010, México D.F. 